JIIP: Jurnal Ilmiah IImu Pemerintahan

Volum 5, Nomor 1, Tahun 2020

DOI: $10.14710 /$ jiip.v5i1.7318

\title{
Inovasi Pemberdayaan Masyarakat Desa: Peran Kepemimpinan Lokal dalam Perspektif Relasi Antar Aktor
}

\author{
Kushandajani ${ }^{1}$, Indah Ayu Permana ${ }^{2}$ \\ ${ }^{1}$ Departemen Politik dan Pemerintahan, Universitas Diponegoro \\ ${ }^{2}$ Magister IImu Politik, Universitas Diponegoro
}

Dikirim: 2 Maret 2020

Direvisi: 31 Maret 2020

Diterbitkan: 15 April 2020

\begin{abstract}
Intisari
Desa adalah struktur administrasi terendah di Indonesia, sehingga posisi desa adalah paling dekat dengan masyarakat. Untuk itu, desa memegang peran penting dalam kerangka pembangunan nasional. Di masa lalu, Desa Melung di Kabupaten Banyumas, dianggap sebagai salah satu desa terbelakang. Namun sekarang, Desa Melung mampu mentransformasikan dirinya melalui program pemberdayaan desa yang inovatif, yang disebut Desa Melek Internet. Fokus penelitian ini terletak pada kepemimpinan kepala desa dalam membangun keterlibatan para aktor dengan peran mereka masingmasing dalam merancang dan menerapkan program inovasi. Penelitian dilakukan dengan pendekatan penelitian studi kasus, dengan teknik pengumpulan data wawancara mendalam kepada beberapa informan kunci. Hasil penelitian menunjukkan bahwa kemampuan kepala desa untuk membangun jaringan antar aktor, merupakan kunci keberhasilan dalam merancang dan secara simultan mengimplementasikan program inovasi pemberdayaan masyarakat.
\end{abstract}

inovasi; pemberdayaan komunitas desa; pemerintah desa; kepemipinan lokal; relasi antar aktor

\section{Pendahuluan}

idak bisa dipungkiri bahwa upaya meningkatkan kesejahteraan rakyat harus dimulai dengan memberdayakan potensi ekonomi pedesaan, mengingat sebagian besar angkatan kerja berpendidikan rendah ada di desa (Noorsy, 2007). Salah satu upaya meningkatkan kesejahteraan masyarakat desa adalah melalui kebijakan penguatan desa, dengan melahirkan Undang-Undang (UU) No. 6 Tahun 2014 tentang Desa. Keberadaan UU tersebut memuculkan rasa pesimis, mengingat struktur pemerintahan desa tidak dikonstruksi sebagaimana pemerintah daerah yang mampu melaksanakan kewenangan yang diserahkan pemerintah pusat. Namun di sisi lain keberadaan UU tersebut juga melahirkan optimisme, mengingat keberadaan desa sudah mapan menghadapi perubahan sosial maupun politik sekian lama. UU tersebut tentulah memiliki tujuan sebagai rekayasa sosial, dimana hukum dipandang sebagai instrumen 
untuk melakukan perubahan sosial (Rahardjo, 2006). Hukum menjadi sarana yang sarat dengan keputusan politik. UU No. 6 tahun 2014 tentang Desa jelas merupakan keputusan politik karena dibuat oleh lembaga politik yang memiliki otoritas membentuk hukum (Kushandajani, 2018). Bunyi pasal-pasal yang ada diharapkan bisa menggerakkan semua lapisan masyarakat desa untuk bisa mewujudkan masyarakat desa yang lebih sejahtera dan berkeadilan.

Atas dasar kewenangan desa tersebut maka pemberdayaan masyarakat desa merupakan aspek penting dalam mendorong tumbuhnya masyarakat desa yang mandiri, inovatif dan kreatif dalam segala aspek kehidupan(Azwardi, 2004). Untuk itu, kemampuan kepala desa dalam memberdayakan masyarakat di desa, tentu akan berdampak pada tingkat partisipasi masyarakat, yang merupakan pendukung utama tata pemerintahan desa (Kushandajani \& Astuti, 2016). Program pemberdayaan memang ditujukan untuk memulihkan potensi yang ada di desa dengan pelibatan penuh oleh masyarakatnya (Sumodiningrat, 2007) . Masyarakat memiliki peran penting dalam menjalankan program pemberdayaan masyarakat di desanya, karena dalam hal ini masyarakat bukan hanya menjadi objek tetapi juga subjek. Perumusan program pemberdayaan masyarakat desa harus menggunakan metode bottom up karena hakikatnya pemberdayaan masyarakat dilakukan agar membuat masyarakat lebih berdaya. Melalui pemberdayaan masyarakat diharapkan dapat menunjang kestabilan ekonomi dan sosial di tingkat desa.

Tantangan kemandirian desa yang diberikan oleh pemerintah pusat membuat desa lebih berinovasi dalam membuat inovasi pemberdayaan masyarakat desa. Inovasi dapat dikatakan sebagai suatu ide, produk, informasi teknologi, kelembagaan, perilaku, nilai-nilai, dan praktik-praktik baru atau objek-objek yang dapat dirasakan sebagai sesuatu yang baru oleh individu atau masyarakat (Rogers, 2010). Inovasi pemberdayaan di tingkat desa dapat dilakukan dengan melihat peluang atau potensi desa yang mungkin belum tergarap dengan baik. Dengan demikian penelitian ini dilakukan untuk mengkaji bagaimana peran pemimpin lokal (kepala desa) dan pelibatan para aktor dengan perannya masing-masing dalam mendesain dan mengaplikasikan program pemberdayaan masyarakat di bidang teknologi informasi. Aktor dalam riset ini adalah semua elemen yang terhubung dalam sistem yang nantinya akan membentuk jaringan secara alamiah (Hapsari, Sarwono, \& Eriyanto, 2017).

Riset ini dilakukan di Desa Melung, Kecamatan Kedungbanteng, Kabupaten Banyumas, Provinsi Jawa Tengah, Indonesia. Desa Melung merupakan salah satu desa di Kecamatan Kedung Banteng, Kabupaten Banyumas, Provinsi Jawa Tengah, Indonesia. Desa ini terletak di lereng Gunung Slamet, salah satu gunung berapi terbesar di Pulau Jawa. Desa Melung pernah mendapat label desa tertinggal karena letak desa yang sulit dijangkau kendaraan sehingga masyarakat juga sulit memperoleh informasi dari dunia 
luar. Berangkat dari kesulitan itulah sejak tahun 2008 di bawah kepemimpinan Agung Budi Satrio, Kepala Desa Melung periode 2001-2013 (dua periode kepemimpinan), Desa Melung mulai melakukan sebuah inovasi dengan sebutan Desa Melek Internet.

Desa ini merupakan unit analisis studi kasus ini. Fokusnya adalah peran kepala desa sebagai representasi kepemimpinan lokal dan relasi aktor dalam melakukan upaya pemberdayaan masyarakat di bidang teknologi informasi. Penelitian dilakukan melalui pendekatan penelitian studi kasus. Studi kasus dianggap lebih cocok karena pokok pertanyaan penelitian ini berkaitan dengan "How atau Why", dimana peneliti hanya mempunyai sedikit peluang untuk mengontrol peristiwa-peristiwa yang akan di selidiki dan bilamana fokus penelitiannya terletak pada fenomena kontemporer (masa kini) di dalam kehidupan nyata. Studi kasus sebagai teknik penelitian digunakan untuk menganalisa persoalan dari multi perspektif yaitu perspektif organisasi, situasi, kejadian, dan proses, dengan menjawab pertanyaan penelitian "bagaimana" dan "mengapa" (Cooper \& Schindler, 2006; Creswell \& Clark, 2017; Myers, 2019; Yin, 2003). Dengan demikian studi kasus merupakan pendekatan kualitatif untuk meneliti kasus atau bounded-system dengan menggunakan pengambilan data in-depth seperti interview dan observasi.

Key informant penelitian ini adalah berbagai tingkat strategis pada komponen masyarakat, diantaranya adalah kepala desa, pamong/perangkat desa, penyedia program aplikasi, dan aktor-aktor yang terlibat dalam pengembangan teknologi informasi di Desa Melung. yang diidentifikasi dengan purposive sampling. Purposive sampling untuk studi kasus ini dipilih karena masing-masing sampel memiliki karakteristik, opini, atau perilaku khusus (Cooper \& Schindler, 2006) peran kepemimpinan kepala desa dan relasi antar-aktor dalam pemberdayaan masyarakat. Melalui teknik sampling tersebut peneliti dapat menemukan informan yang paling memiliki kekayaan informasi. Dengan cara ini peneliti mampu mendapatkan pandangan komprehensif dari berbagai sudut pandang. Data studi kasus dikumpulkan dengan interview menggunakan interview guidelines.

Reliabilitas dan validitas dalam phenomenological paradigm tidak dapat dilakukan semudah positivistical paradigm yang menggunakan data kuantitatif. Namun demikian mengacu pada Collis and Hussey bahwa penelitian yang melibatkan sejumlah anggota tim penelitian ini harus membandingkan interpretasi data oleh sejumlah anggota peneliti dan mendiskusikan hasilnya dalam sejumlah forum pertemuan (Ji \& Hussey, 2009). Adapun validitas penelitian ini ditentukan dengan memastikan bahwa key informant merupakan orang-orang yang benar-benar memiliki kapasitas di dalam menjawab sejumlah pertanyaan dalam in-depth interview (Ji \& Hussey, 2009). 


\section{Kepemimpinan Kepala Desa dan Inovasi Pemberdayaan}

Tahun 2005 Desa Melung masih menyandang desa tertinggal. Lalu pada tahun 2008 Agung Budi Satrio, Kepala Desa Melung periode 2001-2013, melahirkan inisiatif untuk memasang jaringan internet modem dengan Telkom Flexy yang disebarkan ke tiga titik pemancar grumbul (= setara Rukun Warga/RW). Kegiatan awal ini dilakukan dengan cara mengumpulkan dana swadaya antara pemerintah desa dengan pihak Sekolah Dasar (SD) dan Sekolah Menengah Pertama (SMP) untuk berlangganan internet.

Langkah kedua, Kepala Desa mewajibkan seluruh perangkat di kantor desa untuk bisa mengoperasikan gadget dan belajar mengisi berita desa setiap harinya. Langkah ketiga, memperluas akses internet pada tahun 2009-2010 dari Telkom Flexy berganti menjadi Speedy dengan 7 titik akses yang kecepatannya lebih jauh menjangkau hampir ke semua warga desa. Layanan internet ini gratis bagi seluruh masyarakat Desa Melung, bahkan bagi masyarakat yang belum mempunyai gadget diperkenankan untuk menggunakan komputer yang ada di balai desa untuk mengakses informasi sesuai kebutuhannya. Langkah keempat, melakukan pelatihan rutin bagi warga Desa Melung yang ingin belajar mengenai Teknologi Informasi dan Komunikasi (TIK). Langkah kelima, Pemerintah Desa Melung membuat website desa. Website desa dengan alamat https://www.melung.desa.id/ yang diperuntukan bagi seluruh masyarakat yang ingin mengakses informasi tentang Desa Melung.

Tahun 2011 Desa Melung mulai merasakan dampak adanya internet, dimana website Desa Melung mulai dipandang sebagai media yang efektif untuk penyebaran berita dan informasi desa kepada khalayak. Dengan adanya akses internet di desa, pemerintah desa dan masyarakat desa lebih mudah mengakses informasi dari luar desa dan mendorong perkembangan daya pikir dan kreatifitas warga desa, juga memperkenalkan potensi desa, mempromosikan produk desa dan lain sebagainya (Badri, 2016).

Sejumlah media yang berada di kota-kota besar menangkap inovasi ini, akibatnya Desa Melung semakin dikenal khalayak dengan sebutan Desa Melek Internet. Tidak berhenti di situ, desa-desa di sebagian wilayah Indonesia juga mulai melakukan replikasi terhadap inovasi desa yang dilakukan oleh Desa Melung. Pada tahun 2011 para pegiat desa di Indonesia mengadakan pertemuan di Desa Melung, yang membahas tentang Sistem Informasi Desa dan arah pembangunan desa melalui teknologi inormasi dan komunikasi. Pertemuan itu kemudian melahirkan sebuah gerakan yang bernama Gerakan Desa Membangun. Kemudian untuk keberlangsungan Gerakan Desa membangun maka diwadahi dalam lembaga dengan nama Yayasan Gedhe Nusantara yang bergerak di bidang ekonomi kerakyatan, rekayasa teknologi, tata kelola pemerintahan, pendidikan kewargaan yang kesemuanya dilakukan di ranah desa. 
Tahun 2016 Program Desa Melek internet di Desa Melung mulai merambah ke bidang peningkatan ekonomi desa. Hal ini dilakukan dengan cara membuat sistem pasar desa online dalam sebuat situs pasarmelung.id. Dalam program ini Desa Melung dibantu oleh sebuah perusaan aplikasi SiBisnis. Pasar desa online ini merupakan sebuah website jual beli dimana sistem yang digunakan setara dengan E-Commerce BukaLapak.

Tidak bisa dipungkiri bahwa program-program inovasi dilahirkan dari kemampuan dan komitmen berbagai stakeholders, yang pada akhirnya mampu diaplikasikan dalam masyarakat untuk membantu kebutuhannya (Kushandajani, 2015). Peran kepala desa dalam menginisiasi dan melaksanakan program pembangunan di desa tentu menjadi sangat penting. Dilihat dari hasil temuan memperlihatkan bagaimana Kepala Desa Melung mampu menginisiasi dan sekaligus mengaplikasikan gagasan yang sederhana namun membutuhkan kerja keras untuk menghasilkan masyarakat yang paham menggunakan akses internet. Para pemimpin lokal merupakan para pionir dan inovator bagi komunitas lokal (Mohammadpour, Yaghoubi, Kamalian, \& Salarzehi, 2017). Dalam kenyataannya, beberapa studi seperti di daerah Australia Selatan memperlihatkan adanya korelasi kuat antara kepemimpinan dengan tata kelola pemerintahan (Beer, 2014). Akan tetapi, pemimpin di sini bukan dimaknakan sebagai posisi tertentu yang pasti, namun mencakup orang-orang yang memiliki kemampuan tertentu, yang mampu menjembatani penduduk dengan tingkat pemerintah yang lebih luas (Beer, 2014).

Dari dimensi pembangunan kapasitas masyarakat, secara umum dikenal empat kategori strategi yang digunakan dalam membantu mengembangkan kapasitas komunitas, yakni: pengembangan kepemimpinan, pengembangan organisasi, pengorganisasian komunitas, dan kolaborasi antar-organisasi (Chaskin, 2001). Pengembangan kepemimpinan menyangkut keahlian, komitmen, keterikatan, dan efektifitas masyarakat menuju pengembangan kepemimpinan komunitas. Kepemimpinan komunitas didefiniskan sebagai proses kolaborasi dimana para pemangku kepentingan memiliki kapasitas untuk mengambil aksi dalam merespon ataupun mempengaruhi tujuan. Studi yang dilakukan Banyai di Pagudpud (Philiphine) menunjukkan bahwa struktur kebijakan yang efektif menjadi strategi pembangunan kapasitas komunitas yang unggul (Banyai, 2010). Mengacu pada kedua pendapat di atas (Banyai, 2010; Chaskin, 2001), maka apa yang dilakukan Kepala desa Melung bisa juga dimaknai sebagai upaya membangun kapasitas komunitas bidang teknologi informasi melalui langkah-langkah pengembangan organisasi, pengorganisasian komunitas, dan kolaborasi antar-organisasi sebagaimana diuraikan pada penjelasan berikutnya. 


\section{Jejaring Antar Aktor}

Jaringan antar aktor dalam pengembangan TIK di Desa Melung pada tahapan tertentu diperluas, karena pemerintah desa menyadari bahwa pemerintah desa tidak mungkin bergerak sendirian, mereka harus bekerja sama dengan banyak aktor agar Desa Melung bisa berkembang lebih cepat secara pemenuhan kebutuhan. Desa bekerja sama juga dengan banyak aktor lain seperti Relawan Tekonologi Informasi dan Komunikasi (RTIK) Banyumas, Pengelola Nama Domain Internet Indonesia (PANDI), Komunitas Blogger Banyumas, Bhineka Ceria, SiBisnis, serta Kementerian Komunikasi dan Informatika. Keterlibatan banyak aktor ini, dalam konteks ekonomi dan politik, menjadikan perumusan kebijakan sebagai salah satu lahan pertempuran ide bagi para aktor yang terlibat di dalamnya (Caiden and Rubin 2006).

Gambar 1. Peta Aktor dalam Pengembangan Teknologi Informasi di Melung

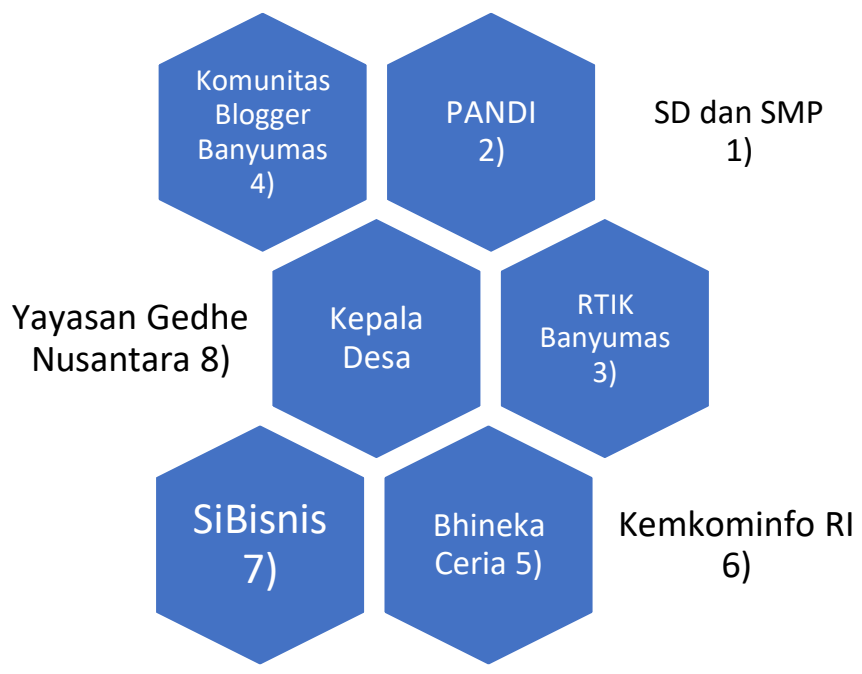

Apa saja peran para kator dalam pengembangan TIK di Desa Melung, bisa diringkas dalam pointer di bawah ini:

1. SD dan SMP di Desa Melung yang pertama kali membantu Pemerintah Desa memobilisasi dana untuk berlangganan internet untuk 3 titik pancar.

2. PANDI (https://pandi.id) bekerjasama dengan RTIK Banyumas dan Kepkominfo RI membentuk suatu domain baru untuk desa yaitu desa.id.

3. RTIK Banyumas (https://rtikbanyumas.or.id/) mendampingi Guru di Pendidikan Anak Usia Dini (PAUD) untuk belajar menggunakan komputer dan memanfaatkan internet untuk metode pembelajaran anak.

4. Komunitas Blogger Banyumas (http://bloggerbanyumas.or.id/) membuat berita-berita tentang pembangunan Desa Melung, juga melakukan pendampingan bagi masyarakat desa untuk membuat tulisan yang baik untuk diberitakan di web desa maupun media sosial.

5. Bhineka Ceria (https://www.bhinnekaceria.com/) melakukan pendidikan dan pelatihan komputer bagi masyarakat desa juga pelatihan dasar penggunaan Word dan Excel. 
Kushandajani \& Indah A. Permana | Inovasi Pemberdayaan Masyarakat Desa: Peran Kepemimpinan...

6. Kemkominfo RI memberikan dukungan ke PANDI dalam bentuk regulasi melalui penetapan Surat Keputusan Menteri Komunikasi dan Informatika (Kominfo) Republik Indonesia Nomor 806 Tahun 2014

7. SiBisnis (https://www.sibisnis.co.id/) membuat situs e-commerce pasarmelung.id dengan konsep pasar desa online.

8. Yayasan Gedhe Nusantara (https://www.gedhe.or.id/) mewadahi semua kegiatan yang dilakukan oleh para pegiat desa dalam Gerakan Desa Membangun. Gerakan Desa membangun diinisiasi saat para pegiat desa berkumpul di Desa Melung tanggal 24 Desember 2011 lewat Lokakarya Desa.

Melihat hasil keterlibatan aktor dengan perannya masing-masing menunjukkan bahwa kepemimpinan kepala desa mampu membangun jejaring kerjasama dengan berbagai aktor, bahkan mampu menginisiasi terbentuknya Gerakan Desa Membangun (GDM) yang mewadahi para pegiat desa Indonesia. Hal ini sejalan sebagaimana disampaikan Öztürk, dkk bahwa 'Organisasi selalu membutuhkan aktor yang memiliki sudut pandang berbeda. Aktor organisasi yang memiliki nilai budaya yang berbeda dapat memperkaya modal pengetahuan organisasi dan menjadi pemimpin di mata masyarakat' (Öztürk, Varoğlu, \& Varoglu, 2017). Dalam konteks Desa Melung, Kepala Desa memiliki visi yang berbeda dan melompat ke depan dibanding masyarakat desa umumnya. Dengan nilai-nilai kekinian yang dimiliki, Kepala Desa mampu mendorong perubahan desa melalui inovasi pemberdayaan desa. Ini menandakan bahwa para pemimpin perlu memiliki pendekatan inovatif untuk mendorong terciptanya iklim dan budaya inovatif dalam organisasi yang dipimpinnya (Supriyono \& Trisnawati, 2015). Salah satu syarat kepemimpinan yang berhasil dilakukan kepala desa adalah kemampuan dalam melakukan penguatan partisipasi dan menciptakan konsensus diantara masyarakat untuk meningkatkan kemampuan self-organizer (Palmer, 2007).

Jika merujuk empat bentuk kekuasaan di bawah kondisi sosial dan teknologi seperti saat ini yakni: Networking Power, Network Power, Networked Power, dan Network-making Power (Castells, 2011), maka bentuk yang ada di Desa Melung lebih cocok menggunakan bentuk Network Power dimana "the power resulting from the standards required to coordinate social interaction in the networks. In this case, power is exercised not by exclusion from the networks but by the imposition of the rules of inclusion" (Castells, 2011).

Bagaimana keberlangsungan Desa Melek Internet kemudian? Tidak bisa dipungkiri bahwa perkembangan internet sudah sangat maju, dimana tiap individu saat ini bisa mengakses segala informasi melalui internet masing-masing sehingga "program" Desa Melek Internet sudah tidak populer lagi.

"Kalau untuk sekarang, pengembangan dari program itu paling untuk memaksimalkan pelayanan di desa, tata kelola desa kemudian pelayanan dengan 
aplikasi e-melung dimana masyarakat desa bisa mengakses berita-berita terkini desa. Aplikasi tersebut juga bermanfaat untuk peningkatan ekonomi juga melalui iklan-iklan desa yang bisa di tampilkan di aplikasi. Kami juga memaksimalkan dengan grup WhatsApp dan Facebook juga untuk jual beli produk masyarakat desa" (wawancara dengan Khoerudin)

Situs e-commerce pasarmelung.id dengan konsep pasar desa online yang dibuat oleh SiBisnis yang semula diharapkan dapat membangun ekonomi desa lewat penjualan produk desa secara online tidak berkembang secara menggembirakan, sehingga pada bulan ke-6 Pemerintah Desa Melung menutup situs tersebut. Hal ini diakui oleh pengelola website, bahwa "Kendalanya adalah masyarakat belum mengetahui bagaimana kemudian transaksi dilakukan, bagaimana pengiriman barang, merepon tuntutan pembeli, dan sebagainya" (wawancara dengan Margino).

Di sini terlihat bahwa masyarakat desa belum siap menerima perubahan budaya dalam perdagangan, dari tradisional yang membutuhkan interkasi langsung tatap muka menjadi interaksi lewat internet. Dengan demikian tidak semua tingkat kepemimpinan inovatif berkorelasi positif dengan kreatifitas sosial masyarakatnya (Eisele, 2017). Meskipun demikian, upaya kepala desa saat itu yang berupaya membuka akses masyarakat terhadap berbagai informasi, mendorong masyarakat untuk belajar mengelola data, membuat web ataupun situs, telah mampu mendorong pihak-pihak luar untuk ikut ambil bagian dalam pemberdayaan desa, khususnya di bidang teknologi informasi. Dengan demikian, kepala desa secara empiris pembangunan dan kebijakan terbukti berkontribusi bagi pengurangan kemiskinan dan peningkatan kesejahteraan dalam kehidupan masyarakat (Kabeer \& Natali, 2013).

\section{Penutup}

Berdasar temuan riset ada beberapa simpulan penting. Pertama, upaya Kepala Desa Melung untuk menghadirkan akses internet bagi warga desa merupakan bentuk leadership development. Kemampuan menginovasi gagasan dalam lingkup komunitas Desa Melung yang awalnya merupakan desa tertinggal lalu dikenal sebagai Desa Melek Internet di Indonesia, merupakan upaya dalam pengembangan kepemimpinan tersebut. Hasilnya Inovasi ini menjadi model pemberdayaan masyarakat di bidang IT dan direplikasi di banyak desa di Indonesia. Pengembangan kemampuan kepemimpinan ini berlanjut melalui terbentuknya Gerakan Desa Membangun dan berlanjut pada pendirian Yayasan Gedhe Nusantara yang bergerak di bidang ekonomi kerakyatan, rekayasa teknologi, tata kelola pemerintahan, pendidikan kewargaan di desa. Dengan demikian kepemimpinannya telah berkembang di luar sekat Desa Melung, dan merambah di tingkat nasional. Kedua, inovasi pemberdayaan masyarakat yang awalnya bertujuan meningkatkan asupan informasi bagi masyarakat, berkembang menjadi arena promosi desa melalui kemampuan Kepala Desa Melung "mengundang" aktor-aktor lain 
di luar desa untuk ikut mensukseskan Desa Melek Internet. Masing-masing aktor berkontribusi melalui arahan dari kepala desa. Dengan demikian, kemampuan kepala desa dalam melakukan kolaborasi antar-organisasi terwujud dalam studi ini. Ketiga, pengorganisasian komunitas merupakan bagian yang tersulit dari pengembangan kapasitas komunitas (masyarakat desa) karena membutuhkan pendampingan terus menerus sampai komunitas siap menjalankannya secara mandiri. Kepala desa dituntut kemampuannya untuk menularkan dan meyakinkan gagasannya ke banyak orang untuk mendapatkan dukungan, sehingga Desa Melek Internet bisa terwujud dan bisa dimanfaatkan masyarakat untunk pengembangan potensi yang sudah ada.

\section{Ucapan Terima Kasih}

Penulis berterima kasih kepada Fitriyah yang berkontribusi mengulas artikel ini ketika masih menjadi draf penelitian.

\section{Pendanaan}

Penulis tidak menerima bantuan pembiayaan untuk penelitian, kepenulisan (authorship), dan publikasi dari pihak manapun.

\section{Daftar Pustaka}

Azwardi. (2004). Kemampuan Kepemimpinan Kepala Desa Dalam Pemberdayaan Masyarakat. Yogyakarta: Gadjah Mada Press.

Badri, M. (2016). Pembangunan Pedesaan Berbasis Teknologi Informasi Dan Komunikasi (Studi Pada Gerakan Desa Membangun). Jurnal Dakwah Risalah, 27(2), 62-73.

Banyai, C. (2010). Community capacity building and local policy: An example from Pagudpud, the Philippines. Asia Pacific World, 1(2), 83-108.

Beer, A. (2014). Leadership and the governance of rural communities. Journal of Rural Studies, 34, 254-262.

Castells, M. (2011). Network theory| A network theory of power. International Journal of Communication, 5, 15.

Chaskin, R. J. (2001). Building community capacity: A definitional framework and case studies from a comprehensive community initiative. Urban affairs review, 36(3), 291-323.

Cooper, D. R., \& Schindler, P. S. (2006). Business research methods: Empirical investigation. Journal of service research, 1(2), 108-128.

Creswell, J. W., \& Clark, V. L. P. (2017). Designing and conducting mixed methods research: Sage publications.

Eisele, P. (2017). Assessment of leadership for innovation and perceived organizational innovativeness: Differences between self-reported individual and social creativity. International Journal of Organizational Leadership, 6, 470-480. 
Hapsari, D. R., Sarwono, B., \& Eriyanto, E. (2017). Jaringan Komunikasi Dalam Partisipasi Gerakan Sosial Lingkungan: Studi Pengaruh Sentralitas Jaringan terhadap Partisipasi Gerakan Sosial Tolak Pabrik Semen Pada Komunitas Adat Samin di Pati Jawa Tengah. Jurnal Komunikasi Indonesia, 6(2), 120-128. doi:10.7454/jki.v6i2.8712

Ji, C., \& Hussey, R. (2009). Business research: a practical guide for undergraduate \& postgraduate students. In: Basingstoke: Palgrave Macmillan.

Kabeer, N., \& Natali, L. (2013). Gender Equality and Economic Growth: Is there a WinWin? IDS Working Papers, 2013(417), 1-58.

Kushandajani, K. (2015). Inovasi Manajemen Pemerintahan Daerah dalam Penanggulangan Kemiskinan di Kota Pekalongan. Jurnal Ilmiah IImu Pemerintahan, 1(1), 49-58.

Kushandajani, K. (2018). Bekerjanya Hukum Tentang Desa di Ranah Pemberdayaan Politik, Sosial, dan Ekonomi Perempuan Desa. Masalah-Masalah Hukum, 47(4), 413-429.

Kushandajani, K., \& Astuti, P. (2016). Managing Village Governance Based On Mutual Assistance (Gotong Royong). Paper presented at the International Conference on Ethics in Governance (ICONEG 2016).

Mohammadpour, S., Yaghoubi, N. M., Kamalian, A. R., \& Salarzehi, H. (2017). Authentic leadership: a new approach to leadership (describing the mediatory role of psychological capital in the relationship between authentic leadership and intentional organizational forgetting). Available at SSRN 3335745.

Myers, M. D. (2019). Qualitative research in business and management: Sage Publications Limited.

Noorsy, I. (2007). Maksimalkan Potensi Petani Dan Ekonomi Desa. Suara Karya.

Öztürk, A., Varoğlu, M. A., \& Varoglu, D. (2017). A critical review of implicit leadership theory on the validity of organizational actor-national culture fitness. International Journal of Organizational Leadership, 6, 456-469.

Palmer, C. (2007). The role of leadership in the collective enforcement of community property rights in Indonesia. Society and Natural Resources, 20(5), 397-413.

Rahardjo, S. (2006). Ilmu Hukum, Cet. VI, Bandung: Citra Aditya Bakti.

Rogers, E. M. (2010). Diffusion of innovations: Simon and Schuster.

Sumodiningrat, G. (2007). Pemberdayaan sosial: kajian ringkas tentang pembangunan manusia Indonesia: Penerbit Buku Kompas.

Supriyono, B., \& Trisnawati. (2015). Innovative Public Leadership (Case Study on Innovative Food Policy for SME's in Sidoarjo Regency). Procedia-Social and Behavioral Sciences, 211, 1057-1063. doi:10.1016/j.sbspro.2015.11.141

Yin, R. K. (2003). Case study research: Design and methods sage. Thousand Oaks. 
Kushandajani \& Indah A. Permana | Inovasi Pemberdayaan Masyarakat Desa: Peran Kepemimpinan...

\section{Daftar Informan}

Agung Budi Satrio, Kepala Desa Melung Periode 2001-2013, wawancara hari Sabtu, 9 Februari 201.

Khoerudin, Kepala Desa Melung Periode 2014-2019, wawancara hari Minggu, 10 Februari 2019.

Margino, Kepala Urusan Keuangan di Kantor Desa Melung dan Admin Website Melung, wawancara 14 Februari 2019.

\section{Tentang Penulis}

Kushandajani adalah dosen Departemen Politik dan Pemerintahan, Fakultas IImu Sosial dan IImu Politik, Universitas Diponegoro. Memiliki area kajian seputar pemerintahan dan pemeberdayaan desa.

Indah Ayu Permana adalah Alumni Magister Ilmu Politik Universitas Diponegoro Tahun 2019. 